\title{
Socioeconomic Status and Its Effect on Teacher/Parental Communication in Schools
}

\author{
Raymond J Ankrum $^{1}$ \\ ${ }^{1}$ Northeastern University, Boston, MA, USA \\ Correspondence: Raymond J Ankrum, Northeastern University, Boston, MA, USA. E-mail: rankrum@rcsli.org \\ Received: January 1, 2016 \\ Accepted: January 18, $2016 \quad$ Online Published: January 21, 2016 \\ doi:10.5539/jel.v5n1p167 \\ URL: http://dx.doi.org/10.5539/jel.v5n1p167
}

\begin{abstract}
The power of communication and community engagement utilized by teachers to actively involve parents and guardians in the educational process of their children is essential to the growth of the students. An important component to student motivation is a teacher's ability to leverage parental/guardian relationships. A teacher's ability to form partnerships with parents to help motivate student achievement is an unmeasurable intangible. Teacher interactions with parents/guardians can make or break the student's relationships with the teachers. Teachers should think of parents as thought-partners in providing rigorous, meaningful education to students. Parents should think of teachers as extended family to students. The partnership between parent and teacher should bridge the gap in the child's education. Extraneous factors such as the Socio-economic status of families should never play a role in how teachers communicate with parents.
\end{abstract}

Keywords: socioeconomic status, teacher communication, critical communication pedagogy

\section{Introduction}

Nobel laureate James Heckman, drawing on his own studies and the work of others, has written extensively about gaps between socioeconomically disadvantaged and advantaged students in both cognitive skills and what he calls non-cognitive or "soft skills" - traits that include motivation, the ability to work with others, the ability to focus on tasks, self-regulation, self-esteem, and the ability to defer gratification (Heckman, 2011). Indeed, he maintains, these soft skills are critical to success in school and later life, and their importance is often underrated (Heckman, 2008). Heckman notes that family factors can influence children from as early as when they are in the womb. By the time they enter school, children from socioeconomically disadvantaged families possess lower levels of cognitive and non-cognitive skills and lag far behind their more advantaged peers. Even worse, these gaps have been shown to persist as children age (Heckman, 2008, 2011).

Moreover, a child's capability to succeed in school depends on how successfully the child is managed by his/her parents in the home environment. It is an environment where the child learns the skills, attitudes and behavior which could mold them into a productive and successful student. However, not every child comes from a home that could provide them with the requisite educational resources necessary for their academic success. In accordance with that, a parent's socioeconomic status plays an important role in providing these educational resources and it appears to impose the greatest impact on the child's educational outcomes (Vellymalay, 2012a).

\section{Literature Review}

Research in parent involvement, (Midraj \& Midraj, 2011) shows that involvement at home has a more significant impact on children's attainment than parent involvement in school activities. Kingsley (2011) carried out a study to analyze the link between parental school involvement and the academic achievement of young students from diverse socio-economic backgrounds between the ages of (15 and 20), the results indicate a positive and significant correlation between mothers' school involvement and the academic achievement of the students.

Howe and Simmons (2005) stated that communication needs to occur regularly and frequently between the teachers and parents about the child in their care. Jeynes (2003) found that parent involvement (e.g., communicating with the school, checking homework, encouraging outside reading and participating in school activities) benefited African-Americans and Hispanic/Latinos more than it did Asian Americans.

Epstein (2005) contended that data from parents in the most economically depressed communities does not support the idea that poor families do not have the same goals as middle class families. Furthermore, it was 
determined that if schools took on parental involvement as a serious part of the organization and ensure that all parents have opportunities for involvement, then social class and parents' level of education decrease or disappear as important factors.

Numerous studies with samples differing in ethnicity and income have demonstrated that both of these dimensions of the home-school mesosystem are associated with student academic engagement and achievement (Boethel, 2003). For example, Rimm-Kaufman et al. (2005) found that kindergarten teachers' reports of parents' attitudes toward education predicted child participation and engagement after accounting for SES and maternal sensitivity.

Ronald Ferguson's researched based tips for "high-achievement parenting" suggests that parents promote reading at home, discuss reading materials with their children in ways that encourage children to enjoy learning, and seek opportunities at home to discuss and apply what children are learning in school, among other activities. Ferguson further recommends that parents set clear and firm rules about homework, television watching, and other daily activities, and that they actively seek out-of-school opportunities and extracurricular activities that reinforce school lessons, and encourage exploration and creativity, and develop children's special talents (Ferguson, 2007a).

Other scholars maintain that social context can lead some children to perceive that certain types of behavior, such as spending time on homework, are pointless and "not for people like me" if they form their identity in a context that provides no example of how academic achievement might be relevant to their personal goals (Oyserman \& Destin, 2010, p. 1002). As Tamera Murdock explains, categories - whether racial, ethnic, gender or other-help students define who they are and construct a vision of who they might become. Contexts in which students are able to view academic achievement as a realistic aspect of their group identity and develop positive images of that identity can foster motivation (Murdock, 2009, p. 451).

In the article Investigating Parental Involvement by DeTorres (2010), the author elicited research to support the claim that parents that are involved, and better equipped to accommodate their students to experience success in school. The United States government is familiar with the benefits of parental involvement for students and has made multiple efforts to push for more parent involvement in the school systems (Abdul-Adil \& Farmer, 2006). The effects of these acts can be seen in many School Improvement Plans (SIPs). The last goal in the Piney Point Elementary School (PPES) SIP is that they want "increased communication, collaboration, and partnerships with all stakeholders", and parents are listed as one of the stakeholders (Piney Point Elementary School Improvement Plan, 2008, p. 28).

Low SES families are often working all of the time to take care of their families, and they have no time to participate in their child's education on campus (Ratcliff \& Hunt, 2009). Based on a study involving low SES mothers, mothers want to be involved in their child's education, but the other problem is that they are less comfortable around teachers, and so they do not get involved (Machen, Wilson, \& Notar, 2005). Turney and Kao (2009) found in their research that Hispanic and Asian parents who were not born in the USA were almost three times more likely to feel unwelcome at their children's school than white Americans. African American parents face more obstacles, including safety and travel issues, and not feeling welcome, than any other group born in the USA (Turney \& Kao, 2009).

In a study where community members knew that their community was characterized by lower SES families and knew of the difficulties that lower SES families face, the community still viewed low SES parents who were not involved on school grounds negatively (Taliaferro et al., 2009). As for schools located in low SES communities, they are less likely to invite parents to be involved at school (Van Velsor \& Orozco, 2007).

In the classroom Latino parents do not understand the expectations of their involvement, and teachers might not begin to contact the parents to get them involved until late in the year (Desimone, 1999). Low amounts of teacher-initiated contact are partially due to the fact that "low income immigrant parents are often viewed [by teachers] as being indifferent to their children's schooling" (Orozco, 2008, p. 22). This can especially be true of newer teachers who, with little experience in working with parents, tend to feel more vulnerable and uncomfortable (Addi-Raccah \& Ainhoren, 2009).

Teachers receive very little or no preparation in building successful alliances with parents or supportive and warm relationships with students. In a national study of 3,595 kindergarten teachers, Early, Pianta, Taylor, and Cox (2001) found that although teachers were unlikely to receive training in building home-school connections, those who did were much more likely to use all types of strategies to promote a successful transition to school, including making personal contacts with parents. Ina synthesis of the literature on early home-school connection, Boethel (2003) reported that the most individualized, relationship-building activities tend to be the least used and that urban schools and schools serving more minority children were least likely to use higher intensity contacts. 
In the article economic status and patterns of parent-adolescent interactions Chen and Berdan (2006) take on the enormous task of analyzing communication patterns amongst lower and higher SES families. Lower family Socioeconomic Status (SES) is associated with a variety of child and family outcomes, including harsher discipline practices, less parent-child communication, and greater child externalizing behavioral problems (Bradley \& Corwyn, 2002; Elder, Vannguyen, \& Caspi, 1985; McLoyd, 1998; Smetana, Crean, \& Daddis, 2002).

Den Tandt reports "Traditional' nuclear families married couples with children now make up barely more than a third of families, 31.9\%. That's well down from $37.4 \%$ in the 2001 census" (2012). In this day and age, families less are frequently made up of both parents, than in the past. Den Tandt reports that the number of single-parent homes has also "grown nearly $10 \%$ since the last census, with the number of male lone-parent families up $16.2 \%$ " (2012). There is evidence to suggest that positive reciprocity or synchrony between parents and children is beneficial for child and family outcomes; however, this research to date has focused on young children and on positive behaviors (Harrist \& Waugh, 2002).

The present study is unique in (1) focusing on the period of adolescence in studying reciprocity in parent-child interactions; and (2) investigating both positive and negative behaviors for reciprocity. This research seeks to advance our understanding of SES-related family relationship characteristics in two ways. First, we test how families from different SES backgrounds differ in reciprocity of parent and adolescent behaviors during interactions (DeTorres, 2010).

In contrast, parents with low socioeconomic status often find themselves struggling to make ends meet causing them to not have any time to spare for their children in imparting values, good habits, manners (Saifi \& Mehmood, 2011) - leaving children to not receive the needed proper nurturing they need to succeed in school. Research found that when families who were not very involved in their children's school became more involved in the school, their children's literacy improved (Dearing, Kreider, Simpkins, \& Weiss, 2006). Moreover, Xu et al. (2010) found that parental involvement at school positively affected self regulated learning of fifth graders. But while resources can limit parents' ability to become involved, that should not be taken to mean that their desire to do so is also limited; research has found that although parents with scarcer resources may be less active in school activities, they can still be entirely aware and supportive of their children's academic progress (Grolnick, Friendly, \& Bellas, 2009).

Given the multitude of demands and stressors in the lives of lower SES families, having times where one family member can be withdrawn and experience reduced positive affect from others may be beneficial in this context, and may explain associations with better relationship quality. Limitations to the present study include the cross-sectional nature of the study, and the modest sample size. The correlational nature of the study makes directionality unclear; that is, family interaction patterns could shape family relationship quality, or relationship quality could determine interaction patterns (DeTorres, 2010).

\section{Participants}

The researcher is a school leader who has built a massive network of colleagues that have leadership roles at schools throughout the United States. The researcher reached out to those colleagues and explained the extent of the research being conducted, and asked if they would distribute survey questions to participants in their schools. In all cases the participants in the survey were certified teachers. The school leaders were more than happy to oblige as all felt the research was meaningful, impactful, and could be instrumental in changing how teachers interact with parents.

\section{Apparatus \& Materials}

The researcher explained to the school leader sharing the link to the survey that they should explicitly say to the participants of the survey that the survey was voluntary, and participants could choose to either partake in the research or not partake, at no penalty or judgment. In total, forty-two (42/115) 36.5\% of participants responded to the survey. The race, demographics, and socioeconomic status of the survey participants are unknown to the researcher.

The three schools combined have a total of 115 teachers. The Likert survey was composed of three questions, with responses ranging from 1-5, 1 representing strong disagreement, and 5 representing strong agreement, respectively. The survey was created using google forms, which also collects and analyzes the data as well. 


\section{Procedure}

The administered survey tool is a Likert survey, consisting of three questions pertaining to teacher interactions with parents, and how socioeconomic status may or may not play a role in those interactions. The survey link was sent to school leaders from various regions of the country. One school is located in Newark, NJ, another is located in Baton Rouge, La, and the last administered school is located in Calverton, NY. Each school leader sent the link to the participants on their staff as directed by the researcher and informed the participants that the survey was optional (See Appendix A).

\section{Discussion}

The claims are powerful and unequivocal: "when schools work together with families to support learning, children tend to succeed not just in school, but throughout life" (Henderson \& Berla, 1997, p. 1). "The shared interests and investments of schools, families, and communities create the conditions of caring that work to "over determine' the likelihood of student success" (Epstein, 1995, p. 703).

Griffin, Case, and Siegler (1994) noted that parent's active participation in small group mathematical activities led to improvement in their children's numeracy skills. For instance, playing games at home such as Building Block and Big Math can significantly impact children's mathematical development (Clements \& Lewis, 2009). Reading books at an early age and having students receive help from their parents or guardians with their school homework can also foster children's mathematical development (Padavick, 2009).

As educators, we have to look critically at why families are so apprehensive to become involved in our school communities. We also have to look at ways to better accommodate the needs of the parents, by making them feel like thought-partners, and a part of the team. Family/school relationships should be looked upon as an extension of the family. However, clear reasons have not been identified as to why families from low SES backgrounds often do not participate in educational programs and activities, and what else can be done to increase their participation (Cross et al., 2009).

It has been shown that teachers, schools, and educators cannot easily change parental involvement structures, but communication between parents-child, parents-teachers, and parents-school can change parents' attitudes and beliefs about mathematics (Yan \& Lin, 2005). Much research has shown the relationship between parental beliefs and attitudes, including the expectations of parents, target orientations, and ability beliefs' children espouse (Friedel, Cortina, Turner, \& Midgley, 2007).

\section{Hypothesis}

In conducting this research, I expected (a) the results to conclude that socioeconomic status plays a major role in how teachers interact with parents, and (b) parents, regardless of socioeconomic status want to be actively involved in their child's education.

\section{Results}

Socioeconomic economic status is a variable that can't be controlled by students that are being educated in our schools. Regardless of their financial circumstances, we owe it to our students to give them our best. Consequently, biases exist in how we interact with the parents of our students. This research highlights the existence of said biases, and looks at ways to move beyond that bias.

Survey question one analyzed if low income families are less involved in their child's education than families that are more economically affluent. Over $50 \%$ of the participants agreed that socioeconomic status was a determiner in the level of activity displayed by parents of students that are disadvantaged.

Survey question two analyzed if socioeconomic status played a role in how teacher communicate with parents. Over $60 \%$ of the participants believe that socioeconomic does play a role in how they interact with parents.

Survey question three analyzed if communication with parents had an impact on the educational outcomes of the students. Over $85 \%$ of the participants believe that parent communication plays a vital role in the success of the students.

\section{Hypothesis One}

The results conclude that socioeconomic status plays a major role in how teachers interact with parents. Although not as overwhelming as I thought it would be, the survey yields that socioeconomic status does in fact play a role in how teachers interact with parents. Although this is not the sole descriptor, it's unfortunate that students aren't viewed on their ability alone. Students can't change their immediate circumstances, and should not be held accountable for such. 


\section{Hypothesis Two}

Parents, regardless of socioeconomic status want to be actively involved in their Child's education. Hypothesis two was upheld tremendously by the surveys, with over $80 \%$ of participants in agreement. Parents, regardless of their socioeconomic status want to play a role in their child's education. It's imperative that school systems think outside the box to afford parents the opportunities to be involved. The results from the survey yield similar results to the literature. However, upholding the literature is not enough. We must come up with captivating ways to eliminate the barriers that exist in our educational system.

\section{Study Limitations}

One such limitation is the amount of questions administered in the survey. Standard Likert surveys have at least five questions. The rationale behind only selecting three questions was to ensure attentiveness and truthfulness on behalf of the survey participants. Rather than overburden the participants with a variety of questions that basically asked the same thing in different ways, the researcher decided to condense and summate the questions. In my experience administering surveys, subjects tend to lose focus based on the length of the survey. Other limitations include but are not limited to not capturing the race of the participant. Different demographics view issues related to parenting, and school involvement through a different lens.

\section{Further Research}

For full partnerships to work, relationships must be characterized by mutual trust and respect and parties must engage in an on-going exchange of information, agree on goals and strategies, understand one another's expectations, and share rights and responsibilities (U.S. Department of Education, 1994). School Development Program (SDP), which, in addition to a number of other school improvements, includes parents in social events, education classes, volunteer programs, and decision-making subcommittees and teams (Comer \& Haynes, 1992). Teachers are expected to develop diverse mechanisms for communicating with parents and an ability to tap the parent network to elicit family views on children's progress (Epstein, 1995). Consequently, different people have different views on subjects pertinent to this strand of research. Capturing the the views of teachers based on their race, demographics, and socioeconomic status to analyze the results to show multilayered societal perceptions related to the socioeconomic status and its impact on parent-teacher relationships would be interesting. Comparing and contrasting the various stereotypes that follow race relations, relating to how people raise their children would be fascinating research. There is very limited research that hones in on the effectiveness of upbringings by a particular race of people. Exploring that dichotomy to determine best practices for raising children would be practical. Of course, poverty, and socioeconomic status would continue to be variables in the research. However, finding ways to limit its impact would be an interesting wave of research to embark upon.

\section{References}

Abdul-Adil, J. K., \& Farmer, A. D. Jr. (2006). Inner-city African American parental involvement in elementary schools: Getting beyond urban legends of apathy. School Psychology Quarterly, 21(1), 1-12. http://dx.doi.org/10.1521/scpq.2006.21.1.1

Addi-Raccah, A., \& Ainhoren, R. (2009). School governance and teachers' attitudes to parents' involvement in schools. Teaching and Teacher Education, 25(6), 805-813. http://dx.doi.org/10.1016/j.tate.2009.01.006

Bornstein, M. C., \& Bradley, R. H. (Eds.). (2003). Socioeconomic status, parenting, and child development. Mahwah, NJ: Lawrence Erlbaum.

Boethel, M. (2003). Diversity: School, family, and community connections. Annual Synthesis 2003. Austin, TX: Southwest Educational Development Laboratory, National Center for Family and Community Schools: 2003. Retrieved February 18, 2005, from http://www.sedl.org/connections/resources/diversity-synthesis.pdf

Bradley, R. H., \& Corwyn, R. F. (2002). Socioeconomic status and child development. Annual Review of Psychology, 53, 371-399. http://dx.doi.org/10.1146/annurev.psych.53.100901.135233

Chen, E., \& Berdan, L. E. (2006). Socioeconomic status and patterns of parent-adolescent interactions. Journal of Research on Adolescence, 16(1), 19-27. http://dx.doi.org/10.1111/j.1532-7795.2006.00117.x

Clements, P., \& Lewis, A. E. (2009, April). The effectiveness of the big math for little kids curriculum: Does it make a difference? Paper presented at the annual meeting of the American Educational Research Association, San Diego, CA.

Comer, J. P. (1992). Educational accountability: A shared responsibility between parents and schools. Stanford Law \& Policy Review, 3, 113-122. 
Cross, C. T., Woods, T. A., \& Schweingruber, H. (Eds.). (2009). Mathematics learning in early childhood: Paths toward excellence and equity. Washington, DC: National Research Council.

Dearing, E., Kreider, H., Simpkins, S., \& Weiss, H. B. (2006). Family involvement in school and low-income children's literacy performance: Longitudinal associations between and within families. Journal of Educational Psychology, 98, 653-664. http://dx.doi.org/10.1037/0022-0663.98.4.653

Den Tandt, M. (2012, September 19). The non-conventional family boom-Is social conservation dead politically? National Post. Retrieved from http://fullcomment.nationalpost.com/

Desimone, L. (1999). Linking parent involvement with student achievement: Do race and income matter? Journal of Educational Research: Heldref Publications, 93(1), 11-30. Retrieved from http://search.ebscohost.com/login.aspx?direct=true\&db=tfh\&AN=2489627\&site=ehost- live

DeTorres, M. (2010). Investigating parental involvement. Retrieved from http://www. smcm.edu/educationstudies/pdf/rising-tide/volume-3/melissa-detorres-mrp.pdf

Early, D. M., Pianta, R. C., Taylor, L. C., \& Cox, J. J. (2001). Transition Practices: Findings from a national survey of kindergarten teachers. Early Childhood Educational Journal, 28, 199-206. http://dx.doi.org/10.1023/A:1026503520593

Elder, G. H., Vannguyen, T., \& Caspi, A. (1985). Linking family hardship to children's lives. Child Development, 56, 361-375. http://dx.doi.org/10.2307/1129726

Epstein, J. L. (2005). School-initiated family and community partnerships. In T. Erb (Ed.), This we believe in action: Implementing successful middle level schools (pp. 77-96). Westerville, $\mathrm{OH}$ : National Middle School Association.

Epstein, J. L. (1996). School/family/community partnerships: Caring for the children we share. Phi Delta Kappa, 76, 701-712.

Fassett, D., \& Warren, J. (2007). Critical communication pedagogy. Thousand Oaks, CA: Sage.

Friedel, J. M., Cortina, K. S., Turner, J. C., \& Midgley, C. (2007). Achievement goals, efficacy beliefs, and coping strategies in mathematics: The roles of perceived parent and teacher goal emphases. Contemporary Educational Psychology, 32, 434-458. http://dx.doi.org/10.1016/j.cedpsych.2006.10.009

Ferguson, R. F. (2007b). Parenting practices, teenage lifestyles, and academic achievement among African-American children. Focus, 25, 18-26.

Giroux, H. A. (1994). Disturbing pleasures: Learning popular culture. New York: Routledge.

Griffin, S., Case, R., \& Siegler, R. S. (1994). Classroom lessons: Integrating cognitive theory and classroom practice. In K. McGilley (Ed.), Right start: Providing the central conceptual prerequisites for first formal learning of arithmetic to students at risk for school failure (pp. 25-50). Cambridge, MA: MIT Press.

Grolnick, W. S., Friendly, R. W., \& Bellas, V. M. (2009). Parenting and children's motivation at school. In K. R. Wentzel, \& A. Wigfield (Eds.), Handbook of Motivation at school (pp. 279-300). New York \& London: Routledge.

Harrist, A. W., \& Waugh, R. M. (2002). Dyadic synchrony: Its structure and function in children's development. Developmental Review, 22, 555-592. http://dx.doi.org/10.1016/S0273-2297(02)00500-2

Hauser, R. M., \& Warren, J. R. (1997). Socioeconomic indexes for occupations: A Review, update, and critique. In A. E. Raftery (Ed.), Sociological Methodology (pp. 177-298). Cambridge, MA: Basil Blackwell. http://dx.doi.org/10.1111/1467-9531.271028

Heckman, J. J. (2011). The American family in black and white: A post-racial strategy for improving skills to promote equity. Daedalus, the Journal of the American Academy of Arts \& Sciences, 140, 70-89. http://dx.doi.org/10.1162/daed_a_00078

Heckman, J. J. (2008). Schools, skills, and synapses. Economic Inquiry, 46, 289-324. http://dx.doi.org/10.1111/j.1465-7295.2008.00163.x

Henderson, A. T., \& Berla, N. (Eds.). (1997). A new generation of evidence: The family is critical to student achievement. Washington D.C.: Center for Law and Education.

Holliday, A. E. (1986). Home-high school communication and collaboration are plus factorsó The question is How? Journal of Educational Public Relations, 8(4), 4-7. 
Howe, F., \& Simmons, B. J. (2005). Nurturing the parent-teacher alliance. Phi Delta Kappa, Educational Module, 533.

Jeynes, W. H. (2003). A meta-analysis - the effects of parental involvement on minority children's academic achievement. Educational and Urban Society, 35, 202-218. http://dx.doi.org/10.1177/0013124502239392

Kingsley, N. (2011). Parental School Involvement: The Case of Ghana. Journal of Emerging Trends in Educational Research \& Policy Stud, 2(5), 378.

Machen, S. M., Wilson, J. D., \& Notar, C. E. (2005). Parental involvement in the classroom. Journal of Instructional Psychology, 32(1), 13-16.

McLaren, P. (2003). Life in schools: An introduction to critical pedagogy in the foundation of education. Boston: Allyn \& Bacon.

McLoyd, V. C. (1998). Socioeconomic disadvantage and child development. American Psychologist, 53, 185-204. http://dx.doi.org/10.1037/0003-066X.53.2.185

Midraj, S., \& Midraj, J. (2011). Parental involvement and grade four students' Arabic reading achievement, European Journal of Educational Studies, 3(2), 245-260.

Murdock, T. B. (2009). Achievement motivation in racial and ethnic context. In K. R. Wentzel, \& Wigfield (Eds.), Handbook of motivation at school (pp. 433-461). New York \& London: Routledge.

Orozco, G. L. (2008). Understanding the culture of low-income immigrant Latino parents: Key to involvement. School Community Journal, 18(1), 17. Retrieved from http://search.ebscohost.com/login.aspx?direct=true \&db=eric\&AN=ED494603\&site=ehos t-live

Oyserman, D., \& Destin, M. (2010). Identity-based motivation: Implications for intervention. The Counseling Psychologist, 38, 1001-1043. http://dx.doi.org/10.1177/0011000010374775

Padavick, J. (2009). Parental involvement with learning and increased student achievement. Doctoral study in teacher Walden University.

Piney Point elementary school improvement plan. (2008). Retrieved from http://www.smcps.org/schools/docs/Piney\%20Point\%20Elementary\%202008-2009\%20SIP\%20Final.pdf

Ratcliff, N., \& Hunt, G. (2009). Building teacher-family partnerships: The role of teacher preparation. Education: Project Innovation, Inc., 129(3), 495-505. Retrieved from $\mathrm{http}: / /$ search.ebscohost.com/login.aspx?direct=true $\& \mathrm{db}=\mathrm{tfh} \& \mathrm{AN}=37138538 \&$ site=ehost- live

Rimm-Kaufman, S. E., La Paro, K. M., Downer, J. T., Pianta, R. C. (2005). The contribution of classroom setting and quality of instruction to children's behavior in kindergarten classrooms. The Elementary School Journal, 105, 377-394. http://dx.doi.org/10.1086/429948

Smetana, J. G., Crean, H. F., \& Daddis, C. (2002). Family processes and problem behaviors in middle-class African American adolescents. Journal of Research on Adolescence, 12, 275-304. http://dx.doi.org/10.1111/1532-7795.00034

Sprague, J. (1992). Expanding the research agenda for instructional communication: Raising some unasked questions. Communication Education, 41(1), 1-25. http://dx.doi.org/10.1080/03634529209378867

Taliaferro, J. D., DeCuir-Gunby, J., \& Allen-Eckard, K. (2009). "I can see parents being reluctant”: Perceptions of parental involvement using child and family teams in school. Child and Family Social Work, 14, 278-288. http://dx.doi.org/10.1111/j.1365-2206.2008.00594.x

Turney, K., \& Kao, G. (2009). Barriers to school involvement: Are immigrant parents disadvantaged? Journal of Educational Research, 102(4), 257-271. Retrieved from $\mathrm{http}: / /$ search.ebscohost.com/login.aspx?direct=true $\& \mathrm{db}=\mathrm{tfh} \& \mathrm{AN}=36419490 \&$ site=ehost-live

U.S. Department of Education. (1994, September). Strong families, strong schools: Building community partnerships for learning. Washington, D.C.: Author.

U.S. Department of Education, National Center for Education Statistics. (2000). The Condition of Education 2000, NCES 2000-602. Washington, D.C.: Government Printing Office.

Van Velsor, P., \& Orozco, G. L. (2007). Involving low-income parents in the schools: Community centric strategies for school counselors. Professional School Counseling: American School Counselor Association, 11(1), 17-24. http://dx.doi.org/10.5330/PSC.n.2010-11.17 
Vellymalay, S. (2012a). Parental Involvement at Home: Analyzing the Influence of Parents' Socioeconomic Status. Studies in Sociology of Science, 3(1), 1-6.

Xu, M., Kushner Benson, S., Mudrey-Camino, R., \& Steiner, R. (2010). The Relationship between Parental Involvement, Self-Regulated Learning, and Reading Achievement of Fifth Graders: A Path Analysis Using the ECLS-K Database. Social Psychology of Education: An International Journal, 13(2), 237-269. http://dx.doi.org/10.1007/s11218-009-9104-4

Yan, W., \& Lin, Q. (2005). Parent involvement and mathematics achievement: Contrast across racial and ethnic groups. The Journal of Educational Research, 99(2), 116-127. http://dx.doi.org/10.3200/JOER.99.2.116

\section{Appendix A}

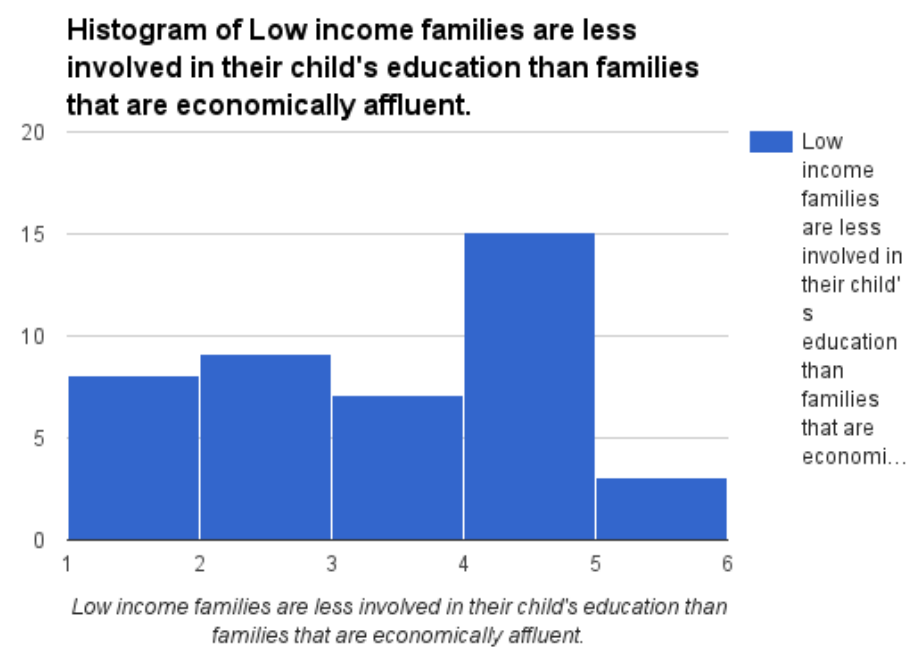

Histogram of Communication with parents has an impact on student educational outcomes.
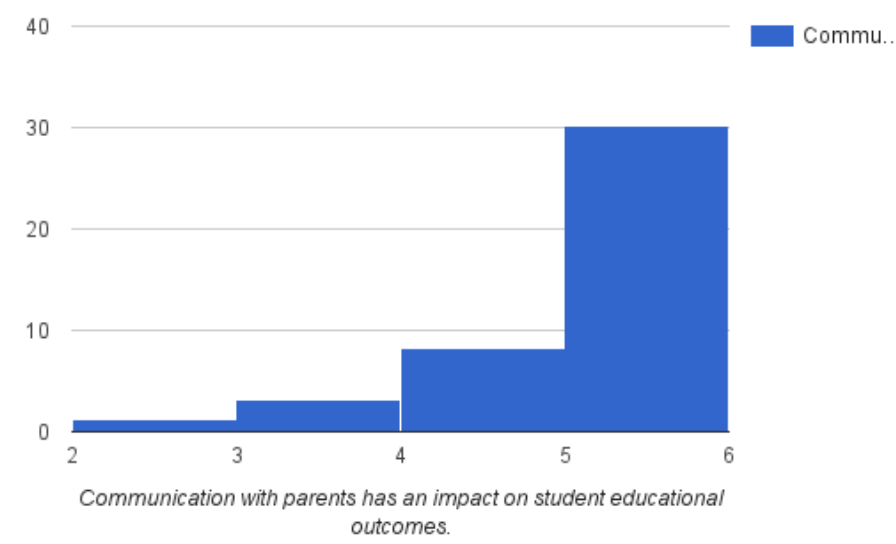


\section{Histogram of Socioeconomic status plays a role in how teachers communicate with parents.}

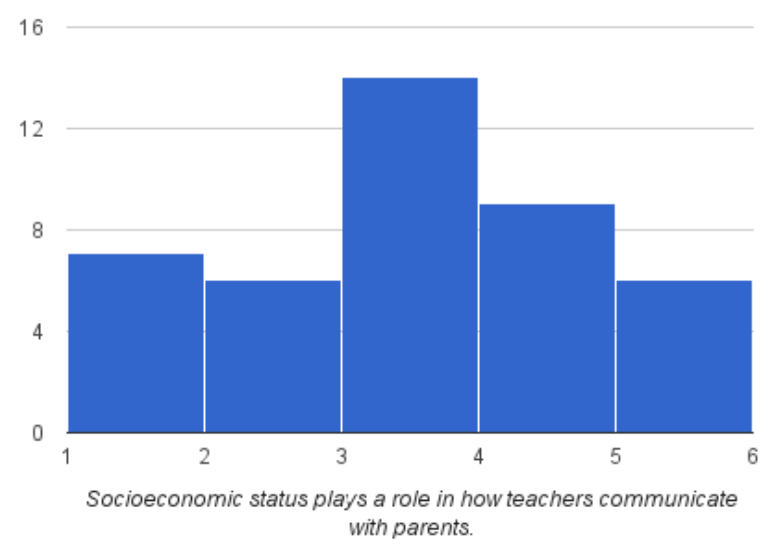

\section{Copyrights}

Copyright for this article is retained by the author(s), with first publication rights granted to the journal.

This is an open-access article distributed under the terms and conditions of the Creative Commons Attribution license (http://creativecommons.org/licenses/by/3.0/). 